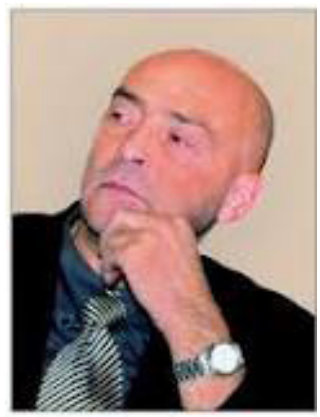

\author{
L. Markin, O. Besedin, K. Isayeva, \\ M. Doroshenko-Kravchyk \\ Danylo Halytsky Lviv National Medical University
}

\title{
Etiopathogenesis and Histogenesis of Ovarian Tumors
}

Introduction. Ovarian tumors rank the second place among all neoplasms of female reproductive organs. According to the data of different authors, the incidence of ovarian tumors has increased from $6.0-11.0 \%$ to $19.0-25.0 \%$ in the last 10 years. Benign forms prevail and constitute $75.0-80.0 \%$; among them, 25.0-30.0\% are tumor-like processes. Malignant tumors occur in $20.0-25.0 \%$ of cases $[7,13,14,24,25,27]$. Benign ovarian tumors are the serious medical, economic and social problem. They often develop in women of childbearing age, affect the reproductive potential, and, respectively, demographic situation in the country, future womens' health as it is known that early iatrogenic ovarian failure, early menopause, and all associated complications can occur after surgeries. Besides this, the majority of them have a tendency to become malignant. Worldwide, approximately 226 thousand of new ovarian malignant tumors cases and, respectively, 141 thousand of deaths are recorded every year $[7,9,24]$. According to the data of National Cancer Registry, mortality and morbidity indices among the female population in 2008-2016 years in cases of malignant ovarian neoplasms were significantly higher compared with the mortality indices in cases of cervical or uterine cancers.

All these facts require the development of new approaches to early diagnosis, effective treatment and, primarily, prevention of ovarian tumors. However, the process of tumor transformation of the cells has not been studied completely. The underlying cause of this is the damage of the cell genetic material, which results in impairment of cell division, growth and differentiation controlling mechanisms, as well as mechanisms of apoptosis. Thus, determination of the main risk factors, knowing the etiological causes and substantial understanding of pathogenic mechanisms of ovarian cancer development on molecular-genetic level will enable to conduct the appropriate prophylaxis and improve the medical aid provided to such patients.

The aim of the study. To review and summarize the published investigations devoted to the problems of etiology and pathogenesis of different ovarian tumors according to their histological structure.

Materials and methods. The content analysis, method of systemic and comparative analysis, bibliosemantic method of studying the actual scientific researches concerning the etiology and pathogenesis of ovarian tumors, differing by the histological structure and the course specificity, were conducted.

The data was searched in scientometric databases:: PubMed-NCBI, Medline, Research Gate, Cochrane Database of Systematic Reviews by such keywords: "etiology", "pathogenesis", "hypothesis", "ovarian benign tumor", "ovarian cancer", "risk factor", "histogenesis", "genetic mutations", "World Health Organization", "FIGO" (fr. - Fédération Internationale de Gynécologie et d'Obstétrique). Totally, 84 English, Ukrainian and Russian sources were analyzed.

Results and discussion. Histological features of ovarian tumors limit the ability to obtain the data about risk factors and accordingly identify their etiology and important pathogenesis pathways. Therefore, many scientific researches are devoted primarily to the study of multiple endogenous and exogenous risk factors.

Among the females, risk groups for ovarian tumor development are identified, requiring often lifelong monitoring by the specialists. Predominantly, these are the women with genetic predisposition, high infectious index and frequent inflammatory processes in the reproductive organs, impairment of the menstrual function, endometriosis, infertility, uterine leiomyoma, human papilloma virus and herpes virus type II, pelvic surgeries, and irrational use of contraceptives [13, $24,27]$. Ovarian tumors are often associated with obesity, thyroid disorders, diabetes mellitus and hereditary endocrine diseases $[1,3]$.

The main risk factors for ovarian tumor development based on modern views are mentioned below $[3,6,8$, 19, 24, 27, 29, 30]. Genetic mutations: inherited genetic mutations of breast cancer (BRCA) genes are the strongest risk factor. 
Women with a BRCA type 1 gene mutation have about the 40.0 to $60.0 \%$ lifetime risk for ovarian cancer. Women with a BRCA type 2 gene mutation have about 10.0 to $30.0 \%$ lifetime risk for ovarian cancer. These gene mutations are also associated with increased risks for breast cancer, fallopian tube cancer, and pancreatic cancer. Other genetic mutations are also associated with increased risk for ovarian tumor - serine/threonine kinase 11 (STK11) (J. Peitz - H. J. Jagers syndrome), deoxyribonucleic acid (DNA) repair genes (H. T. Lynch syndrome - hereditary non-polyposis colorectal cancer), RAD51C, DICER, tumor protein (TP) 53 mutations etc., as well as complicated genetic history of cancer of the mammary glands, ovaries, endometrium, colon, stomach, kidneys, lungs. When a woman describes her family history to her doctor, she needs to mention the history of cancer in women from both mother's and father's sides.

Age: older women have higher risk for ovarian tumor than younger ones. Ovarian cancer usually occurs after menopause, although it can develop in women of all age categories. Ethnicity: Ovarian tumor is more common in white women than in African and American ones. Women who are Ashkenazi (Eastern European) Jewish have a higher risk for ovarian cancer. Endometriosis, a condition in which the cells that line the cavity of the uterus grow in other areas of the body such as ovaries, other pelvic structures, increases the risk for ovarian tumor. Reproductive history: women are at increased risk for ovarian tumor if they began menstruating at early age (before 12 years old), had no children, had their first child after the age of 35 , or experienced early menopause (before the age of 50). Hormone use: women who use hormone therapy after menopause for longer than 5 years may have an increased risk for ovarian cancer. The risk seems to be particularly significant for women who take estrogen-only hormone therapy. The risk is less clear for the combination of estrogen-progestin therapy.

Attempts to classify the ovarian tumor have been originating since 1870 when Heinrich Wilhelm Gottfried von Waldeyer-Hartz tried to differentiate the tumors for the first time. Although histogenesis of certain tumors has not been studied completely yet, and origin of many tumors cannot be determined exactly, and the histological composition is generally accepted basically for tumor classification. Thus, histological confirmation of diagnosis enables distinguishing the tumors by histological type, as ovarian tumor is not only morphological, but also the clinical diagnosis. Currently, the establishment of accurate tumor histogenesis has practical significance, since there is a very perspective direction developed, which is gene therapy.

Hystological and staging classifications of ovariantubal-peritoneal tumors have recently changed. The World Health Organization (WHO) sponsored the review and reclassification of the pathology of the ovarian, tubal and peritoneal tumors and published these updates in $2014[14,24]$. At the same time, the International Federation of Gynecology and Obstetrics reviewed, updated and published the surgical staging system, applied to all histotypes of ovarian, tubal, and peritoneal cancers in 2014 [14, 24]. It incorporates many major scientific advances in understanding the ovarian tumor and recognizes the probable precursor events, lineages, and molecular characteristics.

The highlighting the origin and pathogenesis of ovarian tumor development is complicated. Ovarian tumors arise from three main sources: the first source is, at least, six normal components of the ovary; the second - dystopia, fetal remains; the third - postnatal proliferations, heterotopia and epithelial metaplasia. These sources, which belong to the gonads composition, determine the histological and clinical peculiarities of ovarian tumor. Formation of female reproductive organs from "male" and "female" rudiments - coelomic epithelium and mesenchyme of the testes with further involution of the "male" part, which is found in the hilum of the ovary, promotes that hormone-producing tumors can be both feminizing (granulosa cell tumors, theca cell tumors, mixed tumor), and virilizing (androblastoma, gynandroblastoma, arrhenoblastoma, lipid cell tumors, dysgerminoma, teratoma, choriocarcinoma). There are also mixed tumors: gynandroblastoma, gonadoblastoma.

It is complicated to highlight the origin and pathogenesis of ovarian tumor development has been subjected to significant changes, which were confirmed by new investigations. Accordingly, serous tumors originate from the fallopian epithelium (directly or through the endosalpingitis), endometrioid and clear cell tumors derive from the endometrium (through endometriosis - retrograde blood flow during menstruation), mucinous and transitional cell tumors derive from transitional epithelium in the mesentery region of fallopian tube $[4$, $14,15,17,18,22,30]$.

Although all human ovary cells, including epithelial, stromal, and germ cells, may undergo neoplastic transformation, 80.0 to $90.0 \%$ of ovarian tumors come from the single layer of epithelial cells covering the ovaries $[18,25,27]$. The ovarian surface epithelium is believed to originate from the mesothelium of the embryonic gonad (the mullerian epithelium).

Besides this, there is the dualistic theory of epithelial ovarian tumors pathogenesis, according to which, there are two types: type I and type II [13, 18, 19, 20, 27]. Type I ovarian tumors (about $25.0 \%$ ) include highly differentiated low grade serous, endometrioid, clear cell, mucinous and transitional cell carcinomas. Tumors of type I pass through the stages from serous to borderline cystadenoma, and subsequently become malignant in 5.0-10.0\%. Thus, they are detected at early stages and can be treated surgically, together with this they are characterized by low malignant potential and low sensitivity to cytostatic agents $[17,19,20,29]$. Type II tumors are highly malignant, low-differentiated high grade serous forms (HGSC), undifferentiated carcinomas, and carcinosarcomas with high incidence of mutation of TP53, BRCA type 1, BRCA type 2 genes and marked genetic instability, aggressive biologic behavior. Thus, they are usually detected at late stages, but are highly 
sensitive to chemotherapy, especially to platinum drugs. It is believed that this type of tumor originates "de novo" from the epithelium of fimbriae part of the uterine tubes and/or ovarian surface epithelium [19, 20, 29]. These two types of tumors considerably differ from each other by molecular and genetic peculiarities, and, thus, clinical course, sensitivity to chemotherapy, tendency to relapses, and prognosis, which is very important both from biological and clinical points of view [13, 20, 24, 27].

Literature sources contain the description of frequent combination of serous peritoneal cancer and intraepithelial carcinoma of the endometrium in undamaged by tumor ovaries monitoring. Considering the development of ovarian and peritoneal cancer, one of the key moments of this disease pathogenesis should be highlighted regurgitation in the uterine tubes, which is observed almost in $90.0 \%$ of women during menstruation, associated with transition of the content from the uterus and fallopian tubes to the uterus serous surface, appendages and peritoneum $[6,14,15,17,20,25]$.

In most cases, prior foci of endometriosis occurring due to retrograde flow of endometrium parts in menstruation can be a primary source of endometrioid and clear cell ovarian tumors. Recently, it has been recognized that pathogenesis of endometrioid and clear cell tumors arising from endometriotic cysts is significantly influenced by the microenvironment in which the tumor arises [21, $22,30]$. As the content of the endometriotic cyst includes highly concentrated old blood, and the concentration of iron is markedly high. Free iron is associated with cancer development due to the induction of persistent oxidative stress. The epithelial cells within the endometriotic cyst are exposed to extensive oxidative stress and hypoxia, and, as a result, they are subjected to cellular and DNA damage and have less efficient DNA repair process [21, $22,30]$. The specific correlation between the endometriosis, ovarian malignancy and their epidemiological patterns were studied. For both endometriosis and ovarian carcinoma, increased risks of development were associated with infertility, early menarche, late menopause, nulliparity, and the protective factors were tubal ligation, hysterectomy, the use of oral contraceptives, and pregnancy $[22,30]$.

Mucinous carcinomas develop in association with ovarian teratomas; however, the majority of these tumors do not contain any teratomatous component. Other theories of their origin include mucinous metaplasia of surface epithelial inclusions, endometriosis, and F. Brenner tumors. Mucinous carcinomas and F. Brenner tumors may have similar histogenesis from transitional cell nests at the tubal peritoneal junction [26]. Amplification of 12q14-21 in both mucinous carcinoma and associated F. Brenner tumor was reported recently [23].

According to the WHO criteria, ovarian tumors are classified as benign, low malignant potential (borderline) or malignant. Benign epithelium is characterized by the single or minimally stratified layer of cells or by minimal proliferation or small atypicality degree. Histological structure of the benign tumor is slightly different from the surrounding healthy tissue. Atypical epithelium lining of borderline or low malignant potential tumor is characterized by cellular proliferation and pleomorphism without stromal invasion $[1,11,13]$. Malignant epithelium demonstrates marked atypia, increased mitotic activity, and stromal invasion [13]. Although the histopathologic features of ovarian tumors vary substantially, all tumors exhibit characteristics similar to those of the mullerian epithelium [25].

Although the etiology and underlying molecular mechanisms involved in the development of different phenotypes remain largely unknown, the scientists have suggested several hypotheses to explain the epidemiologic factors.

The first hypothesis postulates that "incessant ovulation" leads to neoplastic transformation of ovarian surface epithelium cells [24]. This hypothesis states that every ovulation creates a wound that ovarian surface epithelium cells repair by undergoing post-ovulation mitosis, proliferation and that the increase of cell proliferation raises the likelihood that the aberrations in DNA repair mechanisms will permit the genetic damage causing the potentially carcinogenic mutations $[10,16,25]$. Several studies have found the evidence that supports the "incessant ovulation" hypothesis. Confirmation of this hypothesis is the decreased risk of developing of ovarian cancer in women with the decreased number of ovulatory cycles (parity, lactation, oral contraceptives, late menarche, and early menopause). However, this hypothesis is inconsistent with the observation that patients with polycystic ovarian syndrome who have decreased ovulatory cycles appear to have the increased ovarian cancer risk [25]. The influence of ovulation stimulators on the formation of tumor processes in the ovaries has not been fully confirmed $[10,13,25]$.

Another hypothesis explaining the relationship between the ovulation history and ovarian tumor risk involves the exposure of ovarian surface epithelium cells to the ovarian stroma [13, 25]. Normally, the ovarian surface epithelium is separated from the stroma by a basement membrane and a layer of thin connective tissue. The formation of the inclusion cyst breaks down that barrier and brings the ovarian surface epithelium cells into the hormonal milieu of the stroma, prompting the neoplastic growth. Combination of endogenous risk factors such as ovarian microenvironment and genetic polymorphisms may act on the epithelial progenitor cells in the ovarian surface epithelium or mullerian epithelium of inclusion cysts, and those cells may have the potential to differentiate into different histologic types of ovarian tumors [19, 20, 21, 25].

The hypothesis of excessive gonadotropin secretion results in intensification of epithelial proliferation and, possibly, tumor transformation. Conditions, accompanied by reduction of estrogen production, lead to compensatory increase in gonadotropic hormones, especially follicle stimulating hormone. High level of gonadotropins has the stimulating effect on the epithelium proliferating. Firstly, diffuse and then focal hyperplasia and proliferation of cell elements, which can lead to tumor formation, 
occur. Stimulating effect of gonadotropic hormones can also result in formation of tumors from embryonic remains. Pathological differentiation of mesenchymal tumors with their subsequent malignization occurs in different age periods under the influence of hormonal and other pathological factors $[4,10,13,25]$.

Along with the impairment of gonadotropic hormones secretion, deviations in estrogen-progesterone interconnections have been revealed. In the presence of tumor-like formations in the ovaries, the concentration of estrogens in the blood increases. It can be confirmed by the high incidence of their combination with hyperplastic processes in the endometrium and mammary glands [10, 13, 25].

Therefore, the impairments in the system "hypothalamuspituitary gland-ovaries" in patients with ovarian tumors are observed, occurring as feedback mechanism and creating favorable background for further progress of the disease.

According to the gonadotropin stimulation hypothesis, epidemiologic observations made in the past decade suggest that several other classes of hormones contribute to ovarian tumor pathogenesis, including androgens, estrogens, progesterone, and insulin-like growth factor I [25]. Most of these hypotheses have been focusing on the influence of risk factors on ovarian surface epithelium cells.

The genetic theory explains the existence of family forms of ovarian cancer (I - family ovarian cancer and lung cancer; II - isolated ovarian cancer, III - H. T. Lynch syndrome II - family cancer syndrome). It is known that mutations were detected in the promoter zone of the antioncogene in ovarian cancer patients in $40.0 \%$ of cases and in benign ovarian tumors in $20.0 \%$ of cases. Complicated heredity is more actively manifested by the action of adverse environmental factors, which reduces the stability of the genome $[5,18,19,20,27$, 29]. According to current scientific literature, hereditary forms of ovarian cancer occur in 6.0-10.0\% of cases. There is inheritance in the recessive type of constitutional and endocrine-exchange features, which is characteristic of ovarian tumors $[18,20]$.

Many authors single out the role of viral, bacterial infection and inflammatory diseases of the pelvic organs in the ovarian structures alterations appearance, whereas high percentage accounts for intracellular specific infection (chlamydiosis $-40.0 \%$, mycoplasmosis $-15.0 \%$ and ureaplasmosis - from 45.0 to $70.0 \%$ of cases) $[1,3,10$, 25]. The inflammatory process results in intensification of anti-inflammatory cytokines expression in the ovaries, which inhibits apoptosis with further disappearing of follicle regression after ovulation, decrease of the steroidogenic enzymes activity in ovarian cortex. In its turn, as the feedback mechanism, this leads to the increase of pituitary-pineal activity.

Contemporary views regarding the ovarian neoplasms prove close correlation between their appearance and the immune system state $[2,12,25,28]$. Tumor processes develop along with the immunodeficiency, promoting its deterioration. It has been proven that the degree of immunodepression correlates with the process extension. Regulatory substances such as T-lymphocytes: T-suppressors and T-helpers are crucial in development or inhibition of immune response. In particular, T-cell immune response is inhibited. Reduction of T-cells with simultaneous activation of suppressive T-lymphocytes promotes the accumulation of tumor cells and interferes with their timely removal. In patients with benign and borderline ovarian tumors, decrease in total number of T-lymphocytes, active T-lymphocytes and T-helpers is observed; inhibition of T-lymphocytes ballast formation occurs. The presence of tumor process in the ovaries is accompanied by changes not only in cell-mediated, but also in humoral immunity. Dysglobulinemia with reduction of $\mathrm{Ig} \mathrm{G}$ level and increase of Ig M concentration is observed.

In recent years, the significant number of investigations which study the growth factors and activity of cytokines have been conducted, [2, 6, 12, 28 ]. Reliably high level of pro-inflammatory cytokine was revealed in blood serum of patients with malignant ovarian tumors compared with its concentration in patients with benign processes. Having studied the macroglobulins in blood serum, peritoneal fluid and content of neoplasms, it has been revealed that their intensive use is aimed at binding of hydrolases, releasing from dead cells. Accumulation of tissue pulls of all classes of microglobulins occurs in malignant tumor tissues, which promotes the protection of tumors against the immunocompetent cells attack [2, $10,12]$.

In the pathogenesis of the ovarian neoplasms development, the disturbance of equilibrium between the processes of proliferation and apoptosis in epithelial cells of tumor tissue plays an important role $[12,25]$. Apoptosis, or programmed death of cells, is one of the most important physiological processes, which is necessary for maintenance of constant cellular composition of organs and tissues, removal of autoreactive cells, which have completed their life cycle. Thus, impairment of genetically programmed processes of cell death can result in uncontrolled cell proliferation by the hormonal system of the body and development of neoplasms in the ovaries. Most often, granulosa cells in the ovaries are subjected to apoptosis, associated with atresia of follicles. Apoptosis in granulosa cells can be inhibited by various growth factors, progesterone, estrogen and gonadotropic hormones. On the contrary, proapoptotic action is typical for different cytokines, androgens and agonists of gonadotropin-releasing hormones. The apoptosis processes in benign epithelial cells of the ovaries are at low level or almost absent, in borderline tumors they reach maximum activity, and in malignant tumors apoptosis intensity again decreases.

Currently, intensive research in the field of morphological and molecular cytogenetics has been conducted. Many detailed data are presented regarding the cytogenetic studies of epithelial ovarian tumors. The molecular pathogenesis of ovarian sex cord-stromal tumor and germ cell tumor are relatively understudied.

Conclusions. Thus, according to epidemiological investigations, neoplasms of the ovaries can be regarded 
as systemic diseases, which occurs on a molecular genetic level with involvement of various endogenous and exogenous factors. The leading role among them belongs to inflammatory processes, endocrine, immune and metabolic disturbances, especially in the presence of genetic polymorphism. However, despite the significant advancements in fundamental science, the causes of tumor appearance and, respectively, the issue of early diagnosis and prophylaxis of the most common neoplasms of the ovaries need further investigation.

\section{References}

1. Сгоров МЮ. Критерії диференціальної діагностики та обгрунтування патогенетичного лікування хворих 3 доброякісними та пограничними епітеліальними пухлинами яєчників [дисертація]. Київ: Національна медична академія післядипломної освіти; 2016. 156 с. (Yegorov MJ. Criteria for differential diagnosis and substantiation of pathogenetic treatment of patients with benign and borderline epithelial ovarian tumors [dissertation]. Kyiv: National Medical Academy of Postgraduate Education; 2016. 156 p.).

2. Егунова МА, Куценко ИГ.Иммунологические исследования в дифференциальной диагностике доброкачественных и злокачественных новообразований яичников на предоперационном этапе. Электронный научный журнал. 2015;1:44-47 (Yegunova MA, Kutsenko IG. Immunological studies in the differential diagnosis of benign and malignant neoplasms of the ovaries at the preoperative stage. Electronic Science Journal. 2015; 1: 44-47). (Russian).

3. Икромова 3М. Соматический и гинекологический сатус женщин репродуктивного возраста с доброкачественными опухолями и опухолевидными образованиями яичников. Вестник Авиценны. 2017;19(1):7-10 (Ikromova ZM. Somatic and gynecological satus of reproductive age of women with benign tumors and tumor-like formations of the ovaries. Avicenna Bulletin. 2017;19(1):7-10). (Tajikistan). https://doi.org/10.25005/2074-0581-2017-19-1-7-11

4. Коган ЯЭ. Актуальные вопросы патогенеза и диагностики опухолей и опухолевидных образований яичников. Практическая медицина. 2018;16(9):34-39 (Kogan YaE. Actual issues of the pathogenesis and diagnosis of tumors and tumor-like formations of the ovaries. Practical Medicine. 2018;16(9):34-39). (Russian). https://doi.org/10.32000/20721757-2018-9-34-39

5. Козаченко ВП. Опухоли стромы полового тяжа. Онкогинекология. 2015;4:42-46 (Kozachenko VP. Tumor stroma tumors. Oncogynecology. 2015;4:42-46 ). (Russian).

6. Макаров ОВ, Нариманова МР. Рак яичников: новое в вопросах этиопатогенеза и диагностики (обзор литературы). Вестник Российского государственного медицинского университета. 2014;4:53-57 (Makarov OV, Narimanova MR. Ovarian Cancer - New in the Questions of Etiopathogenesis and Diagnostics: a Literature Review. Bulletin of the Russian State Medical University. 2014;4:53-57). (Russian).

7. Національний інститут раку. Рак в Україні, 2016-2017. Захворюваність, смертність, показники діяльності онкологічної служби: бюлетень національного канцер-реєстру України [Інтернет]. Київ: Національний інститут раку; 2018 [оновлено 2018; цитовано 2018]. Доступно: http://www.ncru.inf.ua/publications/index.htm (National Cancer Institute. Cancer in Ukraine, 2016-2017. Morbidity, mortality, oncology indicators: Bulletin of the National Cancer Registry of Ukraine [Internet]. Kyiv: National Cancer Institute; 2018 [Updated 2018; cited 2018]. Available at: http://www.ncru.inf.ua/publications/index.htm) (Ukrainian).

8. Паяниди ЮГ, Жорданиа КИ, Логинов ВИ, Чемерис ГЮ, Сивакова НГ. Эндометриоз и эндометриоидный рак яичников. Акушерство и гинекология: Новости. Мнения. 2017;1:44-48 (Payanidi YuG, Zhordania KI, Loginov VI, Chemeris GYu, Sivakova NG. Endometriosis and endometrioid carcinoma. Obstetrics and Gynecology: News. Opinions. 2017;1:44-48). (Russian).

9. Романів МП. Окогінекологічна патологія в структурі захворюваності та смертності населення України. Вісник наукових досліджень. 2017;2:23-24 (Romaniv MP. Oncological pathology in the structure of morbidity and mortality of the population of Ukraine. Bulletin of Scientific Research. 2017;2:23-24). (Ukrainian).

10. Серебренникова КГ, Кузнецова ЕП. Современные представления об этиологии и патогенезе опухолевидных образований и доброкачественных опухолей яичников. Саратовский научно-медицинский журнал. 2010;6(3):552558 (Serebrennikova KG, Kuznetsova EP. Modern views on aetiology and pathogenesis of tumor growths and benign ovarian tumors. Saratov Journal of Medical Scientific Research. 2010;6(3):552-558). (Russian).

11. Суханова АА, Неспрядько СВ, Мельник НН, Егоров МЮ. Пролиферативная активность и рецепторный статус доброкачественных и пограничных эпителиальных опухолей яичников. Здоровье женщины. 2016;6(112):158164 (Sukhanova AA, Nespryadko SV, Melnik MM, Egorov MYu. Proliferative activity and receptor status of benign and borderline epithelial ovarian tumors. Health of Women. 2016;6(112):158-164). (Ukrainian).

12. Charbonneau B, Good EL, Kimberly R K, Keith L K, Melissa SD. The immune system in the pathogenesis of ovarian cancer. Crit Rev Immunol. 2013;33(2):137-164. https://www.ncbi.nlm.nih.gov/pmc/articles/PMC3940260. https://doi. org/10.1615/CritRevImmunol.2013006813

13. Colombo N, Sessa C, du Bois A, Ledermann J, McCluggage WG, McNeish I et al. ESMO-ESGO consensus conference recommendations on ovarian cancer: pathology and molecular biology, early and advanced stages, borderline tumours and recurrent disease. Annals of Oncology. 2019;30(5):672-705. https://doi.org/10.1093/annonc/mdz062. https://doi. org/10.1093/annonc/mdz062

14. Duska LR, Kohn EC. The new classifications of ovarian, fallopian tube, and primary peritoneal cancer and their clinical implications. Annals of Oncology. 2017;28(8):8-12. https://dx.doi.org/10.1093/annonc/mdx445. https://doi. org/10.1093/annonc/mdx445

15. Erickson BK, Conner MG, Landen CN. The role of fallopian tube in the origin of ovarian cancer. Am J Obstet Gynecol. 2013;209:409-414. http://doi: 10.1016/j.ajog.2013.04.019. https://doi.org/10.1016/j.ajog.2013.04.019

16. Fathalla MF. Incessant ovulation and ovarian cancer - a hypothesis re-visited. Facts Views and Vision Issues in Obstetrics Gynecology and Reproductive Health. 2013;(5):292-297. https://www.ncbi.nim.gov/pmc/articles/PMC3987381.

17. Jie L, Abushahin N. Pang NS, Xiang L, Chambers SK, Fadare O et al. Tubal origin of "ovarian" low-grade serous carcinoma. Modern Pathology. 2011: 24(11):1488-1499. https://doi.org/10.1038/modpathol.2011.106 https://doi. org/10.1038/modpathol.2011.106 
18. Koshiyama M, Matsumura N, Konishi I. Recent concepts of ovarian carcinogenesis: Type I and Type II. Biomed Resours International. 2014;2014:934261. http://dx.doi.org/10.1155/2014/934261. https://doi.org/10.1155/2014/934261

19. Kroeger PT, Drapkin R. Pathogenesis and heterogeneity of ovarian cancer. Current Opinion in Obstetrics and Gynecology. 2017;29(1):26-34. https://doi:10.1097/GCO.0000000000000340.

20. Landen CN, Birrer MJ, Sood AK. Early events in the pathogenesis of epithelial ovarian cancer. Journal of Clinical Oncology. 2008;26(6):995-1005. https://doi.org/10.1200/JCO.2006.07.9970.

21. Mandai M, Matsumura N, Baba T, Yamaguchi K, Hamanishi J, Konishi I. Ovarian clear cell carcinoma as a stressresponsive cancer: influence of the microenvironment on the carcinogenesis and cancer phenotype. Cancer Letters. 2011;310(2):129-133. https://doi.org/10.1016/j.canlet.2011.06.039.

22. Mandai M, Yamaguchi K, Matsumura N, Baba T, Konishi I. Ovarian cancer in endometriosis: molecular biology, pathology, and clinical management. International Journal of Clinical Oncology. 2009;(14):383-391. https://doi. org/10.10076/s10147-009-0935-y.

23. Pejovic T, Bürki N, Odunsi K. Fiedler P, Achong N, Schwartz PE et al. Well-differentiated mucinous carcinoma of the ovary and a coexisting brenner tumor both exhibit amplification of 12q14-21 by comparative genomic hybridization. Gynecologic Oncology. 1999;74(1):134-137. https://doi.org/10.1006/gyno.1999.5402

24. Ray-Coquard I, Morice P, Lorusso D, Prat J, Oaknin A, Pautier P et al. Non-epithelial ovarian cancer: ESMO Clinical Practice Guidelines for diagnosis, treatment and follow-up. Annals of Oncology. 2018;29(4):1-18. https://doi. org/10.1093/annonc/mdy001.

25. Samuel CM, Kwong J, William RW, Samimi G, Ozbun L, Bonome T et al. Etiology and pathogenesis of epithelial ovarian cancer. Disease Markers. 2007;23(5-6):367-376. http://dx.doi.org/10.1155/2007/474320.

26. Seidman JD, Khedmati F. Exploring the histogenesis of ovarian mucinous and transitional cell (Brenner) neoplasms and their relationship with walthard cell nests: a study of 120 tumors. Archives of Pathology and Laboratory Medicine. 2008;132(11):1753-1760. http://doi.org/10.1043/1543-2165-132.11.1753.

27. The Australian Cancer Network and National Breast Cancer Centre. Clinical practice guidelines for the management of women with epithelial ovarian cancer [Internet]. National Breast Cancer Centre, Camperdown, NSW; 2004 [updated 2009; 15; cited 2009]. Available from: http://www.nhmrc.gov.au.

28. Turner TB, Buchsbaum DJ, Straughn MJr, Randall TD, Arend RC. Ovarian cancer and the immune system - the role of target therapy. Gynecologic Oncology. 2016;142(2):349-356. https://doi.org/10.1016/j.ygyno.2016.05.007.

29. Vang R, Levine DA, Soslow RA. Molecular alterations of TP53 are a defining feature of ovarian high-grade serous carcinoma: a rereview of cases lacking TP53 mutations in The Cancer Genome Atlas Ovarian Study. Int J Gynecol Pathol. 2016;35:48-55. https://doi.org/10.1097/PGP.0000000000000207

30. Worley MJ Jr, Welch WR, Berkowitz RS, Ng SW. Endometriosis associated ovarian cancer: a review of pathogenesis. International Journal of Molecular Sciences. 2013;14:5367-5369. https://doi.org/10.3390/ijms14035367

Стаття надійшла до редакції журналу 6.02.2020 p.

\section{Etiopathogenesis and Histogenesis of Ovarian Tumors}

\section{Markin, O. Besedin, K. Isayeva, M. Doroshenko-Kravchyk}

Introduction. Nowadays, the incidence of ovarian tumors has increased from $6.0-11.0 \%$ to $19.0-25.0 \%$, becoming the serious medical, economic and social problem, as they affect the reproductive potential, respectively, demographic situation in the country and future women's health. Besides this, the majority of them have a tendency to become malignant. Also they are one of the causes of high mortality among the female population. Thus, determination of the main risk factors, knowledge of etiological causes and substantial understanding of pathogenic mechanisms of ovarian tumor will enable to conduct prophylaxis of this disease development and improve the medical aid.

The aim of the study. To review and summarize the published investigations devoted to the problems of etiology and pathogenesis of different ovarian tumors according to their histological structure.

Materials and methods. The content analysis, method of systemic and comparative analysis, bibliosemantic method of studying the actual scientific researches concerning the etiology and pathogenesis of ovarian tumors, differing by the histological structure and the course specificity, were conducted.

The data was searched in scientometric databases: PubMed-NCBI, Medline, Research Gate, Cochrane Database of Systematic Reviews by such keywords: "etiology", "pathogenesis", "hypothesis", "ovarian benign tumor", "ovarian cancer", "risk factor", "histogenesis", "genetic mutations", "World Health Organization", "FIGO" (fr. - Fédération Internationale de Gynécologie et d'Obstétrique). Totally, 84 English, Ukrainian and Russian sources were analyzed.

Results. Analysis of modern literature shows that the process of tumor cell transformation has not been fully understood due to their histological features. Nowadays, the numerous endogenous and exogenous risk factors have been identified. And, recently, the traditional theory of the appearance of ovarian tumors 
has undergone the significant changes. Also, several hypotheses have been proposed to explain the epidemiological factors: the continuous ovulation hypothesis, the hypothesis of gonadotropins excessive secretion, the genetic theory, theory of microenvironment and genetic polymorphism. In recent years, the large number of studies are devoted to the study of the immune system state, the process of apoptosis, morphological and molecular cytogenetics.

Conclusions. Thus, according to epidemiological investigations, neoplasms of the ovaries can be regarded as systemic diseases, which occurs on a molecular genetic level with involvement of various endogenous and exogenous factors. However, despite the significant advancements in fundamental science, the causes of tumor appearance and, respectively, the issue of early diagnosis and prophylaxis of the most common neoplasms of the ovaries need further investigations.

Keywords: ovarian tumors, etiology, pathogenesis, histogenesis.

\section{Етіопатогенез і гістогенез пухлин яєчників}

\section{Л. Б. Маркін, О. В. Беседін, К. Ю. Ісаєва, М. В. Дорошенко-Кравчик}

Вступ. Пухлини яєчників посідають друге місце серед усіх новоутворень жіночих статевих органів. За результатами досліджень різних авторів їх частота за останні 10 років збільшилась з 6,0-11,0 \% до 19,025,0 \%. Доброякісні пухлини $є$ важливою медичною, економічною і соціальною проблемою, оскільки доволі часто виникають у жінок дітородного віку, впливаючи на репродуктивний потенціал, а отже, й демографічну ситуацію в країні та жіноче здоров’я загалом. Окрім цього, більшість із них здатна до малігнізації.

Мета. Зробити огляд і узагальнити опубліковані дослідження, присвячені проблемам вивчення етіології і патогенезу різних пухлин яєчників залежно від їх гістоструктури.

Матеріали й методи. Використано контент-аналіз, метод системного та порівняльного аналізу, бібліосемантичний метод вивчення актуальних наукових досліджень стосовно етіології і патогенезу різних за гістостуктурою і перебігом пухлин яєчників. Пошук джерел здійснено у наукометричних базах інформації: PubMed-NCBI, Medline, Research Gate, Cochrane Database of Systematic Reviews за такими ключовими словами: "etiology", "pathogenesis", "hypothesis", "ovarian benign tumor", "ovarian cancer", "risk factor", "histogenesis", "genetic mutations", "World Health Organization", "FIGO" (фp. - Fédération Internationale de Gynécologie et d'Obstétrique). Проаналізовано 84 джерела англійською, українською і російською мовами.

Результати. Аналіз сучасної літератури свідчить, що процес пухлинної трансформації клітин до кінця не вивчений. I хоча до сьогодні виявлено численні ендогенні та екзогенні фактори ризику, гістологічні особливості пухлин яєчників обмежують можливість отримувати інформацію про їх етіологію та важливі ланки патогенезу. За останній час традиційна теорія виникнення пухлин яєчників зазнала суттєвих змін, що підтверджується новими дослідженнями, згідно з якими серозні пухлини походять із епітелію маткової труби, ендометріоїдні та світлоклітинні є похідними ендометрію, а муцинозні та перехідноклітинні зачатків перехідного епітелію в ділянці брижі маткової труби.

Сьогодні запропоновано декілька гіпотез для пояснення епідеміологічних факторів. Відповідно до гіпотези «безперервної овуляції» ушкоджується епітелій яєчників із подальшою регенерацією та можливими генетичними поломками і малігнізацією. За гіпотезою «надлишкової секреції гонадотропінів» це призводить до посилення епітеліальної проліферації і, можливо, пухлинної трансформації. «Генетична» теорія пояснює існування сімейних форм раку яєчників. Значна роль належить вірусно-бактеріальній інфекції та запальним захворюванням органів малого таза у виникненні змін структур яєчників. Сучасні погляди на патогенез новоутворень яєчників засвідчують тісний взаємозв'язок між їх виникненням і станом імунної системи. Пухлинні процеси виникають у зв'язку з імунодефіцитом, провокуючи його поглиблення. Важливу роль відіграє також порушення рівноваги між процесами проліферації і апоптозу. Сьогодні здійснюється багато досліджень, присвячених вивченню чинників росту й активності цитокінів, а також у галузі морфологічної і молекулярної цитогенетики.

Висновки. Новоутворення яєчників можна розглядати як системні захворювання, які виникають на генетично-молекулярному рівні з участю різноманітних ендогенних і екзогенних чинників, провідне значення серед яких мають запальні процеси, ендокринні, імунні та обмінно-метаболічні порушення, особливо за наявності генетичного поліморфізму.

Ключові слова: пухлини яєчників, етіологія, патогенез, гістогенез. 